\title{
Dificultades PROBATORIAS DE LOS ADELANTOS TECNOLÓGICOS*
}

Héctor Eduardo Leguisamón***

(Argentina)

\section{RESUMEN}

Se comienza por examinar el impacto producido por los adelantos científicos y tecnológicos en el Derecho en general, especialmente, en las acciones de filiación con la evolución de los exámenes genéticos y con el advenimiento de la informática.

Luego, se pasa a enfocar el cambio en la preconstitución de prueba que ha producido la tecnología mediante los faxes, correos electrónicos -e-mails-, grabaciones magnetofónicas, videofilmaciones, compact discs, DVD, etc., y las dificultades probatorias que provocan al ser empleados en un proceso judicial como también otros inconvenientes de índole procesal.

Recibido: febrero 16 de 2015 - Aceptado: junio 24 de 2015

* Artículo inédito

Doctor en Ciencias Jurídicas y Sociales por la Universidad del Museo Social Argentino. Profesor titular de Práctica Profesional en la Facultad de Ciencias Jurídicas y Políticas de la Universidad del Museo Social Argentino; profesor invitado en cursos de posgrado y en la Carrera de Especialización en Derecho Procesal Civil de la Facultad de Derecho y Ciencias Sociales de la Universidad de Buenos Aires y Fundesi, y de Especialización en la Función Judicial de la Facultad de Derecho, Ciencias Políticas y Sociales de la Universidad de Morón. Miembro de la Asociación Argentina de Derecho Procesal; del Instituto de Derecho Procesal Civil de la Academia Nacional de Derecho y Ciencias Sociales; del Instituto Iberoamericano de Derecho Procesal, de la Asociación Internacional de Derecho Procesal y de la International Law Association; Director del Suplemento de Derecho Procesal de elDial.com Biblioteca Jurídica Online. Tratadista y autor de diversas obras jurídicas. 
Como punto central del trabajo, se analiza la conceptualización de dichos elementos como documentos y se estudia el valor probatorio que cabe adjudicarles, con citas de fallos jurisprudenciales que han decidido casos concretos.

El estudio se realiza, si bien dentro del marco teórico de la normativa vigente relativa al fracaso de la ley de firma digital, y con referencias al derogado Código Civil y también del nuevo Código Civil y Comercial argentino (con entrada en vigor el $1^{\circ}$ de agosto de 2015), también desde un punto de vista eminentemente práctico, esto es desde el funcionamiento dentro del proceso judicial.

Por otro lado, se examinan las distintas alternativas tendientes a probar la autenticidad de los correos electrónicos (e-mails) y se concluye en que el medio más idóneo es la producción de la prueba pericial a realizar sobre el ordenador (la PC) desde el cual fue supuestamente enviado o recibido el e-mail. Este proceso debe ser llevado a cabo por un ingeniero en sistemas o un experto en criptología o en la especialidad que en el futuro la técnica indique como adecuada, de manera anticipada y complementada con el secuestro del equipo de computación correspondiente, sin que su propietario tenga conocimiento con anterioridad - para evitar el riesgo de que los archivos sean eliminados o alterados-. Lo anterior debe darse bajo la intervención del defensor oficial para que se encuentre garantizado el derecho de defensa del propietario en juicio.

Finalmente, se tratan las dificultades que producen las grabaciones de audio y de imágenes en los medios masivos de comunicación (radio, televisión, Internet) como también otros adelantos tecnológicos que son presentados como prueba documental en el proceso judicial, especialmente, cuando se trata de un daño producido por un medio de comunicación masiva.

Palabras clave: prueba preconstituida, prueba y valor probatorio de los correos electrónicos (e-mails), documentación de grabaciones de audio y de imágenes.

\section{Abstract}

It starts by examining the impact produced by the scientific and technological developments in the law in general, especially, in the actions of filiations with the evolution of genetic testing, and with the advent of computing.

Then, it goes on to focus the change in the preconstitution of evidence that has produced the technology through the faxes, e-mails, taped recordings, video recording, as compact discs, DVD, etc., and the 
probative difficulties that cause it to be employed in a judicial process as well as other disadvantages of procedural nature.

As a focus of the work, it analyzes the conceptualization of such elements like documents and it is studied the probative value that it should be awarded, with appointments of jurisprudential courts that have decided specific cases.

The study is performed within the theoretical framework of the regulations in force concerning the failure of the digital signature law, and with references to repealed Civil Code and also the Argentine new Civil and Commercial Code (with entry into force on 1 August 2015), as well from a highly practical point of view, this is within the operation of the judicial process.

On the other hand, reviews the various alternatives designed to demonstrate the authenticity of the e-mails and it concluded that the most appropriate way is the production of the expert evidence to perform on the computer (PC) from which it was allegedly sent or received the e-mail. This process should be carried out by a systems engineer or a cryptology expert, or the specialty that in the future indicated as the appropriate technique, in advance and complemented with the kidnapping of the computing equipment that is concerned, without the owner having prior knowledge -in order to avoid the risk of the files may be deleted or altered-. This should be giving the official intervention of the official defender in order to guaranteed the proprietary defense right.

Finally, it discusses the difficulties that produce the audio and images recordings in the mass media (radio, television, Internet) as well as other technological advances that are presented as evidence in the judicial process, especially, when it comes to a damage produced by a medium of mass communication.

Key words: preconstituted evidence, proof the probative value of e-mails, documentation of audio and images recordings.

\section{LOS ADELANTOS CIENTÍFICOS Y TECNOLÓGICOS.}

El fin de la centuria y del milenio nos encontró con un desarrollo formidable de la ciencia y de la tecnología. El hombre traspasó límites inimaginables, solo concebibles por autores -y no por todos- de ciencia ficción.

No hace falta mirar hacia atrás para apreciar que a principios del siglo $\mathrm{XX}$ la aviación estaba en ciernes al igual que la navegación submarina. Los vuelos comerciales eran una apetencia de algunos visionarios empresarios que alentaban a los aventureros. No existía la heladera eléctrica, ni la radio y la 
televisión recién vio su nacimiento promediando el siglo. El teléfono (aparato que ahora nos acompaña caminando por la calle glosado al cinturón del caballero o en la cartera de la dama, cuando no directamente en la mano o, en los últimos tiempos, con un aparato de sistema bluetooth adosado a un oído o directamente conectado en el automóvil) estaba dando sus primeros pasos. Hoy en día, los mapas terrestres o cartas náuticas -aunque es recomendable no dejarlos de lado- han sido reemplazados por el GPS (Global Position Satelital), mediante el cual se puede llegar al destino deseado con total precisión, ya que guía de manera satelital al automóvil o a la embarcación.

La exceptio plurium concubentium, otrora defensa por excelencia en las pretensiones de filiación, debido al advenimiento de las pruebas biológicas, ha perdido prácticamente sentido, como también vigor la posesión de estado con sus tradicionales nomen, tractus y fama, elementos antes importantísimos, que aparecen en la actualidad como meramente corroborantes ${ }^{1}$. Hace tiempo, cuando se contaba únicamente con la prueba hematológica que permitía excluir la paternidad pero no afirmarla positivamente, la doctrina y la jurisprudencia sostenían que la negativa a someterse a la prueba biológica creaba una presunción en contra de quien asumía tal actitud procesal ${ }^{2}$, por la década de los años 70, sobrevino la prueba de histocompatibilidad (HLA - Human Lymphocyte Antigen-) que, dirigida originalmente a evitar los rechazos de trasplantes orgánicos en seres humanos, fue aplicada en las investigaciones de filiaciones y, por ser más concluyente que la anterior, robusteció la opinión imperante ${ }^{3}$. Luego, fue superada por la aparición del $\mathrm{ADN}^{4}$. Así, los estudios para la identifi-

$1 \quad$ DUTTO, Ricardo J. "El derecho identitario del niño. Significación y valoración de las pruebas biológicas”. Revista de Derecho Procesal. vol. 2002-2, Santa Fe, Argentina: Rubinzal-Culzoni, 2002. p. 144.

2 BOSSERT, Gustavo A. y ZANNONI, Eduardo A. Régimen legal de filiación y patria potestad -ley 23.264-, pp. 105/106. Buenos Aires: Astrea, 1985. Con citas de BELLUSCIO, Manual. t. II, no 473; BORDA, Tratado de derecho civil -Familia--, t. II, nº 733. Buenos Aires: Abeledo-Perrot.; DÍAZ DE GUIJARRO, Valoración probatoria de la negativa a someterse a la investigación de los grupos sanguíneos, J.A. (Jurisprudencia argentina) 1947-III-216; ZANNONI, Eduardo A., Derecho de familia, t. II, p. 476, n 842; GROSMAN, Cecilia P., Acción de impugnación de paternidad del marido, p. 183, $\mathbb{\$} 56$; CALAROTA, Determinación de la paternidad por el sistema HLA, L.L. (La Ley) 1985A-472; Cám. Nac. Civ. (Cámara Nacional de Apelaciones en lo Civil), sala D, 6/9/1973, E.D. 53-182; íd., sala C, 5/3/1977, L.L. 1977-C-70; íd., sala F, 12/2/1975, E.D. (El Derecho) 67-639; y en contra de MERCADER, Amílcar, La jurisdicción y la prueba. Investigaciones en el cuerpo humano, L.L. 23-120.

3 CORTE SUPREMA DE JUSTICIA DE LA NACIÓN. 1/11/1987, “D., N. N. c/ C., E. J., L.L. 1987-E-404; Cám. Nac. Civ., sala F, 7/3/1989, “G. A., R. N., c/ D., A., L.L. 1989-E-112/3.

4 "El F.B.I. informó al Comité de Tecnología de ADN en ciencias forenses por intermedio de J. W. Hicks que el 33\% de las inclusiones de vínculo por HLA fueron excluidas 
cación de la individualidad de las personas pueden ser resueltos investigando la variabilidad o polimorfismo de la molécula del ácido desoxirribonucleico, cuya sigla es ADN o DNA -según la literatura inglesa- ${ }^{5}$. El examen genético de ADN, correctamente realizado, es en la actualidad el medio científico que alcanza el mayor grado de certeza en la investigación de filiaciones, en tanto que permite excluir la paternidad en un $100 \%$ e incluirla en un $99,99 \%$.

Estos son tan solo algunos de los ejemplos de lo acontecido en los últimos cien años, lapso que, si bien para un mortal es poco más que su vida entera, para la historia de la humanidad significa simplemente un grano de arena en la inmensidad del médano.

La informática es uno de los adelantos tecnológicos más sorprendentes que fue capaz de desarrollar el ser humano. En sus principios se estableció la puja entre el hombre y la computadora. ¿Podría esta derrotar al hombre? Entiendo que el hombre venció con creces, puesto que fue capaz de perfeccionar la tecnología al grado tal que, paradójicamente, casi se ha convertido en un esclavo de la computadora. Todo es manejado por la informática. Sin darnos cuenta se ha producido una invasión de la cibernética en nuestro modo de vida que prácticamente no la notamos hasta que nos falta. Si necesitamos dinero a una hora inconveniente, el cajero automático nos lo proporciona (si antes lo depositamos en la cuenta bancaria, claro está). Nos interesa buscar información sobre algún tema específico, nos conectamos y "navegamos" en la red Internet. Deseamos realizar una compra en cualquier lugar del mundo, utilizamos la tarjeta de crédito, o, si no viajamos, también la podemos hacer vía Internet, y el resumen de la cuenta nos será enviado para que cómodamente la abonemos en nuestro domicilio o bien será debitado directamente de la cuenta bancaria. Nos preocupa el saldo de esta, podemos pedirlo telefónicamente y hasta nos será

por ADN” (DI LELLA, Pedro. Paternidad y pruebas biológicas. Argentina: Depalma, 1997. p. 22).

5 El primero en aplicar los estudios en cuanto a la variación de los VNTR (Variable Number of Tandem Repeats) o "minisatélites" -regiones que se encuentran en el ADN genómico que se caracterizan por la repetición en tandem de una misma secuencia de ADN y son secuencias de nucleótidos de distinta longitud- fue Alec J. Jeffreys en Inglaterra, quien acuñó la expresión de "DNA-fingerprinting" o "huellas dactilares de ADN" (JEFFREYS, Alec J., et al. Individual-specific fingerprints of human DNA, Nature. 314: 67/73, 1985).

6 LEGUISAMÓN, Héctor Eduardo. Las presunciones judiciales y los indicios. ps. 171/176, $2^{a}$ ed. actualizada y ampliada. Santa Fe, Argentina: Rubinzal-Culzoni, 2006.; Prueba cientifica de ADN vs. cosa juzgada en procesos de filiación, ponencia presentada al XXIV Congreso Nacional de Derecho Procesal (Mar del Plata, 2007), Libro de Ponencias, pp. 303/304; página web del Congreso http://www.procesal2007 mdp.com.ar/buscador.htm, y elDial.com DCE2E; y Derecho procesal civil. t. II. Santa Fe, Argentina: Rubinzal-Culzoni, 2009. p. 85. 
remitido un fax o, mejor aún, lo podemos ver directamente o pedir por Internet y lo recibiremos en nuestra cuenta de correo electrónico. Debemos hacer un viaje, efectuamos la reserva telefónicamente y ni siquiera será necesario ir en búsqueda de los pasajes pues nos otorgarán los tiquetes electrónicos y hasta se puede reservar el hotel en el extranjero vía Internet. Necesitamos realizar una comunicación urgente, enviamos un e-mail.

En nuestro específico metier de operadores del Derecho ya no es necesario pasar horas leyendo empolvados repertorios jurídicos, le ordenamos a la computadora personal que realice una búsqueda por nosotros en alguna publicación jurídica "on line". La máquina de escribir manual se ha convertido en una especie en vía de extinción (aunque vale la pena tener una a la mano por si se corta el suministro de energía eléctrica), mientras que las hasta hace no demasiado tiempo modernas máquinas eléctricas, o las posteriores electrónicas, han dejado paso a las computadoras personales y las posteriores notebooks que son llevadas cómodamente colgadas al hombro para trabajar en determinados lugares o aprovechar "tiempos muertos". Hasta para realizar cualquier trámite en una dependencia pública o en una empresa privada será menester efectuar la consulta a una computadora. Claro, el problema se suscita cuando alguien nos dice: "se colgó el sistema".

Sin duda alguna este tremendo adelanto tecnológico se ha incorporado a nuestro modus vivendi. Ya no podemos prescindir de él. Pero al mismo tiempo que brinda confort y disfrute, también es un elemento de potencial riesgo, como acontece, por ejemplo, con los informes comerciales de solvencia económica de los bancos de datos?

La energía atómica también fue uno de esos adelantos científicos que el hombre supo lograr, sin embargo, el mundo estuvo al borde de la destrucción con su constante amenaza. De la misma manera, un indebido empleo de la informática puede producir efectos tan nocivos y destructivos como la energía nuclear. Hay quienes exprimen su ingenio en la búsqueda de burlar y traspasar las barreras de los códigos de seguridad de los sistemas informáticos ("hackers"), como los hay otros que denodadamente, sin escatimar esfuerzos -hasta por diversión-, tratan de elaborar los tan temidos virus que los contaminan y los tornan inoperables. Basta con pensar qué sucedería si se lograra acceder a un sistema informático y se alteraran o fueran destruidos los datos de un sistema de defensa de uno o varios países (como aconteció en el Pentágono de los Estados

Ver LEGUISAMÓN, Héctor Eduardo. El hábeas data y la legislación nacional. Los daños punitivos: una herramienta necesaria. Tesis doctoral defendida y aprobada el 28/4/2011 en la Universidad del Museo Social Argentino, Argentina; a editar por editorial Rubinzal-Culzoni, Santa Fe, Argentina. 
Unidos de Norteamérica) o de un banco mundial; sería factible una guerra mundial o una hecatombe económica.

Así como el desarrollo de la energía atómica tuvo sus límites, la informática también debe tenerlos. Es tarea de los científicos de la tecnología continuar con su expansión en beneficio del hombre, pero también idear dispositivos técnicos que impidan nefastas intromisiones. La tarea de los hombres de Derecho es imaginar con creatividad mecanismos legales no solo para proteger ese desarrollo tecnológico (derecho informático), sino también para intentar anticiparse y prever -a la manera de Julio Verne- los futuros, constantes y vertiginosos adelantos cibernéticos para prevenir los peligros del poder informático.

Es conocido que el Derecho va a la zaga de los descubrimientos y adelantos científicos y tecnológicos, pero podemos afirmar, sin temor a equivocarnos, que la velocidad de estos aumenta cada vez más, ante lo cual se produce la imposibilidad de ser seguidos adecuadamente por el Derecho, lo que aletarga su reacción.

Más allá de la demora en regulaciones sustanciales, esto se evidencia en materia de Derecho probatorio. Los juristas y magistrados deben hacer verdaderos esfuerzos para intentar, al menos, estar al nivel y receptar los beneficios de tales adelantos en provecho del fin último del proceso, este es el establecimiento de la verdad jurídica objetiva, en la medida que humanamente sea posible, la verdad.

Alertaba el maestro argentino Morello:

En el tiempo inmediato, en que seguramente las conquistas científicas nos deslumbrarán aún más, el Derecho deberá hacer un redoblado esfuerzo de superación de sus propios niveles, para no quedar inmovilizado y, al cabo, descompensado. No hay obstáculos infranqueables para que, en ese desafío, se perfeccione desde los dos flancos: la evolución de la ciencia natural y el progreso técnico, por un lado, y el de la apertura y superación de los logros de la ciencia jurídica que manejan los operadores del Derecho en la búsqueda de la verdad, lo que provocará que la cuña científica cobre otro voltaje, desde el encofrado jurídico. Finalmente, importará evitar excesos de posición de uno y otro lado, balanceando, proporcionalmente, el punto adecuado (y dinámico) del equilibrio global. Lo que no podremos esquivar es que la cientificidad de la prueba ha subido a escena y, cada vez, reivindicará, en el espectáculo del proceso, un papel de mayor relieve ${ }^{89}$.

$8 \quad$ La frase última es de BARBOSA MOREIRA, José. "Restricciones a la prueba en la Constitución brasileña". en Revista del Instituto Colombiano de Derecho Comercial. ( ${ }^{\circ}$ 21-22). Bogotá, 1997. pp. 126/138; la cita, que no se refiere a lo que aquí examinamos, está en la última de las páginas individualizadas.

9 MORELLO, Augusto M. La prueba científica. L.L. 1999-C-897. 
Desde esta perspectiva, no se le puede pedir al juez que posea una ciencia igual o superior a la del científico; debemos contentarnos con que el juez controle, adecuadamente, el grado de aceptabilidad -conforme al del conocimiento común- de los nuevos métodos científicos, o bien la racionalidad del procedimiento y conclusiones seguidas que aporta el científico, única manera de que se satisfagan con la lente jurídica los modos de control que posee la "opinión pública" frente a ese cometido ${ }^{10}$.

\section{PRUEBA PRECONSTITUIDA.}

Frecuentemente, los justiciables, ante la existencia de un conflicto y previendo un futuro litigio, preparan la prueba de determinados hechos a fin de hacerla valer llegado el caso. Es lo que se conoce con la denominación de prueba preconstituida. Se ha dicho que:

la intervención del juez en el ordenamiento de la producción de la prueba es la frontera conceptual que determina que una prueba sea preconstituida o sea prueba judicialmente adquirida. La intervención del juez determina la presencia del Estado en el proceso, y es la garantía de seguridad y certeza en la actividad probatoria, circunstancia que no se encuentra presente frente a la prueba preconstituida. Y se ha agregado un elemento subjetivo a dicha distinción, determinando que para hablar de prueba «preconstituida» no basta la circunstancia de que el medio probatorio se haya formado con anterioridad al proceso, sino que es necesario la intención de acordarle tal carácter ${ }^{11} 12$.

$\mathrm{Su}$ valor probatorio no solo depende de la naturaleza, sino de las circunstancias del caso y de los demás elementos colectados en el proceso.

10 FAIRÉN GUILLÉN, Víctor. Doctrina general del derecho procesal. Barcelona: Bosch, 1993. p. 463.

11 FARINA, Marta. "El documento notarial y la prueba preconstituida”, en Revista notarial. Año 83, no 833. La Plata, Argentina: Colegio de Escribanos, 1977: "Dentro de este tipo de prueba, cabe hacer la siguiente distinción: 1) Pruebas que se preparan por adelantado, por pura precaución $y$ sin saber si jamás ha de existir un litigio que haga necesaria su producción; en estos casos se tiene en cuenta la validez del acto, más que su utilización como forma de crear la certeza en el magistrado. 2) Aquellas que se preparan con el fin inmediato de ser utilizadas en un proceso. La distinción tiene importancia por cuanto se ha visto con cierta desconfianza la prueba que se "preconstituye», ante la inminencia de un proceso, sin la intervención de la contraparte".

12 PORZIO, Paula Eugenia. La actividad probatoria preliminar. ¿Sería necesaria su regulación? elDial.com DC101C. 
Si bien en general es mirada con disfavor, porque emana de personas voluntariamente vinculadas a los hechos sobre los cuales certifican o deponen, cuyo conocimiento no se produce por circunstancias casuales, sino intencionalmente, y a requerimiento de la parte interesada, en las averiguaciones de aquel o en la constitución anticipada de una prueba ${ }^{13}$, ha tenido diferente suerte en la jurisprudencia $^{14}$.

13 Cám. Nac. Civ. Sala A, 5/10/1982, “G., M. A. c. E., J. M., E.D. 102-747.

14 Cám. Nac. Trab. (Cámara Nacional de Apelaciones del Trabajo), sala IV, 16/2/1981, “González, Esteves R. A. c/ Buek, Eduardo”, BCNT (Boletín de la Cám. Nac. Trab.) 98137-14; E.D. 93-674: "Resulta irrelevante la circunstancia de que la prueba que acredita la negativa de trabajo haya sido o no preconstituida, por cuanto nuestro sistema procesal se basa en el principio de la «libre apreciación» y no en el de la «prueba legal» (conf. art. 386, C.P.C.C.N.), y por ende, el juzgador puede libre y críticamente inducir de los distintos resultados de los medios probatorios, elementos que lo persuadan acerca de la verdad objetiva (en el caso el trabajador compareció a tomar tareas acompañado de dos testigos)". ARGENTINA. SUPREMA CORTE JUSTICIA DE MENDOZA. Sala I, 4/7/1984, "Pérez, Rogelio H. c/ Peña de Navarro, Carmen" (del voto en disidencia de la doctora Kemelmajer de Carlucci), E.D. del 24/9/1984, p. 3; J.A. 1985-III-296: "El valor probatorio de las actas notariales es el siguiente: desde el punto de vista procesal, la comprobación notarial de hechos solo constituye un medio de prueba de los tantos de que pueden valerse las partes, asemejándose a una suerte de prueba testimonial extrajudicial y preconstituida, aunque sin revestir los caracteres de la prueba testifical propiamente dicha. Y sin gozar de las prerrogativas estatuidas en los arts. 993 a 995 del Cód. Civil, pudiendo ser enervada por prueba en contra, pues en definitiva se trata de un documento notarial unilateral, aunque lo refrende un escribano, sin contralor de la otra parte que no ha sido sujeto instrumental del acto".

Cám. Nac. Civ., sala A, 5/10/1982, “G., M. A. c/ E., J. M., E.D. 102-747: "A los fines de sustentar la acción de filiación extramatrimonial, una grabación magnetofónica no es medio de prueba idóneo para acreditar la existencia de relaciones íntimas entre las partes, en el lapso de la concepción, desde que como medio de prueba es de dudoso valor, más aún si se tiene en cuenta que se trata de una prueba preconstituida a la cual se le debe dar una eficacia relativa, por provenir de quien está interesada en producirla en su favor, careciendo por ello, salvo excepciones, de la objetividad necesaria como para no determinar la conducta ajena en favor propio, o no deslindar aquello que contraríe a sus intereses o propósitos".

Corte Suprema Justicia de Santa Fe, Argentina, 4/6/1997, "Trossero, Pablo A. c/ Veterinaria Ataliva y/u otros", L.L. Litoral 1998-243: "Es inconstitucional la sentencia que condena al demandado a indemnizar los daños y perjuicios derivados de su intervención como médico veterinario con fundamento en la prueba preconstituida producida por el actor sin intervención de aquel, máxime cuando la actuación unilateral del vencedor al vender los animales supuestamente afectados de la enfermedad cuya falta de detección se imputara al profesional, impidió a este acreditar la veracidad de las circunstancias en que cimentó sus argumentos defensivos, importando el pronunciamiento emitido un desconocimiento del derecho de defensa en juicio". 
Cuando hablamos de prueba preconstituida inmediatamente se nos representa la imagen de una constatación realizada por un escribano público, que puede incluir la toma de fotografías, que también certifica el notario.

Sin embargo, esta no es la única forma de preconstituir prueba. Por ejemplo, la comparecencia de un empleado con dos personas de su conocimiento a su lugar de trabajo para que oficien de testigos en caso de mediar negativa de trabajo por parte de su empleador o el intercambio epistolar provocado para fijar posiciones o extraer de su futuro contendiente manifestaciones que lo perjudiquen, son algunas de las formas.

En el caso de la constatación mediante escribano público, en tanto instrumento público, da plena fe hasta que sea redargüida de falsedad por acción penal o civil. No obstante, en este punto interesa distinguir los hechos que fueron verificados personalmente por el oficial público de aquellos que no lo fueron. Los primeros gozan de la presunción legal iuris tantum de verdad de los hechos pasados ante el oficial público (art. 296, inc. $a$, y concordantes del nuevo Código Civil y Comercial argentino -L. 26.994, Boletín Oficial del 8/10/2014-; antes arts. 993, 994 y concordantes del derogado Código Civil argentino), los últimos no ${ }^{15}{ }^{16}$. Así, la certificación por escribano público de

15 Cám. Trab. Córdoba, Argentina. Sala VI, 26/12/1989, "Rosales, Rubén G. c/ Asociación Gremial de Empleados de Comercio", L.L. Córdoba 1991-713: "Carece de eficacia probatoria el relato hecho a la escribana, según el acta notarial, en tanto no ha sido por la deponente reproducido o ratificado ante el tribunal. El principio de inmediación así lo exige, ya que si así no se entendiera bastaría con tomar declaraciones testimoniales ante escribanos e incorporarlas como documental, para reemplazar la relación directa entre los testigos y el tribunal, eliminando también la oralidad de la recepción de tal prueba, con todos los efectos positivos perseguidos por el sistema".

Cám. Civ. Com. y Laboral, Rafaela, Santa Fe, Argentina, 21/8/1996, "De Sem, Miriam c/ Racionave S.R.L., L.L. Litoral 1997-1154: “El sistema instituido por el Código Civil en materia de instrumentos públicos, permite diferenciar la fuerza probatoria de aquellos según las enunciaciones que contengan. En tal sentido, la existencia material de los hechos contemplados en el art. 993 del citado cuerpo normativo solo podrá enervarse mediante la redargución de falsedad civil o criminal, mas respecto de la sinceridad de las enunciaciones a que aluden los arts. 994 y 995, solo se requiere prueba en contrario para su desvirtuación".

Cám. Nac. Civ., sala G, 10/4/1985, "Yun de Lee, Young, Nam c/ Moon, Byung Won”, L.L. 1985-C-267; D.J. (Doctrina Judicial) 1985-4-754: "La afirmación de no haber recibido el precio que la escribana certifica fue pagado en su presencia importa aducir la falsedad de ese hecho, cumplido ante la notaria ya que no se trata de una simple manifestación de partes, susceptible de ser destruida por prueba en contrario, sino de la existencia material de un hecho que el oficial público enunció como pasado en su presencia, respecto al cual la escritura pública hace plena fe entre partes y respecto de terceros mientras no se lo ataque mediante querella o redargución de falsedad (arts. 993 a 995 del Cód. Civil)”. 
una fotografía ilustrativa de daños en una cosa (un inmueble, un automóvil, etc.) goza de la presunción de verdad del estado de la cosa cuando el notario la constató, pero no de la causa que originó los daños que muestra la fotografía ${ }^{17} 18$.

En este sentido, prevé el artículo 312 del nuevo Código Civil y Comercial, que el valor probatorio de las actas notariales se circunscribe a los hechos que el notario tiene a la vista, a la verificación de su existencia y su estado; en cuanto a las personas, se circunscribe a su identificación si existe, y se debe dejar constancia de las declaraciones y juicios que emiten, las cuales deben ser referidas como mero hecho y no como contenido negocial.

En el supuesto de los conocidos del empleado, luego declararán estos en sede judicial, pues para eso lo acompañaron. En el del intercambio epistolar, si no son reconocidas las misivas, se prueba su autenticidad mediante un pedido de informes a la empresa de correos, si se trata de medios fehacientes, o por pericia caligráfica, si es correspondencia común.

Podemos hablar, incluso, de preconstituir prueba mediante la promoción - por denuncia- de una causa penal, como es el caso de los accidentes de tránsito cuando no actúa de oficio la autoridad policial. Así, por ejemplo, en ella se va a producir un informe médico legista sobre las lesiones que presenta la víctima, un informe mecánico con relación a los daños que ostente el automóvil embistente, se recibirán eventualmente testimonios, etc., probanzas que si bien son producidas en un proceso judicial, luego serán evaluadas por un juez distinto al penal, el juez civil que entienda la demanda por daños y perjuicios. Esto es lo que la doctrina denomina prueba trasladada.

Pues bien, la tecnología ha suministrado una serie de elementos que en la actualidad son frecuentemente utilizados para preconstituir prueba (v.gr., faxes, correos electrónicos -e-mails-, grabaciones magnetofónicas, videofilmaciones, compact discs, DVD, etc.), y que, al ser empleados en un proceso judicial, provocan dificultades probatorias, así como también otros inconvenientes de índole procesal.

16 El nuevo Código Civil y Comercial argentino prevé en el artículo 296, inciso $b$, que el instrumento público da plena fe hasta la simple prueba en contrario, en lo que hace al contenido de las declaraciones sobre convenciones, disposiciones, pagos, reconocimientos y enunciaciones de hechos directamente relaciones con el objeto principal del acto instrumentado.

17 Cám. Nac. Civ., sala F, 15/9/1995, "Bejarano, Carlos A. y otro c/ Consorcio de Propietarios Corrientes 4924/26 y otro", L.L. 1997-D-861 (39.739-S): “Las actas de constatación son un medio de prueba de eficacia relativa, pues el notario solo otorga plena fe de la existencia de hechos ocurridos en su presencia mas no de que las afirmaciones efectuadas por quienes concurrieron al acto sean verdaderas".

18 LEGUISAMÓN, Héctor Eduardo. Lecciones de derecho procesal civil. Argentina: Depalma, 2001. ps. 429/430; y, Derecho procesal civil. Op. cit. t. I, pp. 658-659. 


\section{PRUEBA Y VALOR PROBATORIO DEL FAX, DEL CORREO ELECTRÓNICO (E-MAIL) Y OTROS "DOCUMENTOS".}

Se entiende por documento, en sentido amplio, todo objeto capaz de reflejar una manifestación del pensamiento o la existencia de un hecho pasado o presente.

Cuando se habla de "documento", inmediatamente se representa en la mente la imagen de un papel escrito y firmado. Sin embargo, dentro del concepto procesal de prueba documental también queda incluida una diversidad de elementos proporcionados por los adelantos tecnológicos como fotografías (más modernamente digitales), grabaciones magnetofónicas, películas cinematográficas, videocintas, compact discs, DVD, radiografías, dibujos, planos, marcas, cuadros, libros, publicaciones, códigos de barras, faxes, correos electrónicos -e-mail-, mensajes de texto de teléfonos celulares, etc. ${ }^{19} 20$

19 Cám. Civ. y Com. Santiago del Estero, 1ª, Argentina, 16/5/1996, "Napau S.A. c/ Rodríguez, Roberto y otros", L.L. 1997-E-984: "Los dibujos, cuadros, planos, fotografías, radiografías, películas, cintas magnetofónicas y discos con grabaciones se encuentran incorporados al género de los documentos, por imperio de las disposiciones del art. 370, $2^{\circ}$ párr., del C.P.C.C. de Santiago del Estero".

Juzg. Nac. Civil n 67, 25/3/1998, "Díaz de Vivar, Elisa M. c/ Neustadt, Bernardo y otros”, L.L. 1998-C-88: "Los progresos tecnológicos han vuelto anticuadas las garantías del legislador en materia de preconstitución de la prueba, por lo que la preeminencia del instrumento escrito debe ceder su rigidez ante los nuevos medios que el hombre ha producido -en el caso, videocinta. Por ello, se requiere una mayor flexibilización en la admisión de estos y en la libre apreciación de la prueba, sin más prejuicios ni condicionamientos que los de la sana crítica".

Cám. Nac. Trab., sala III, 9/3/2006, causa 27.655/2003, "Montero, Alejandro Oscar c/ Swiss Medical S.A. s/ despido", elDial.com AA3338: "El escribano interviniente dejó asentado que a requerimiento de un representante de la demandada se pide su presencia a efectos de exhibirle tres videos y dicho representante manifiesta que han sido grabados con fecha 6/4/2003, 17/4/2003 y 2/5/2003, en el $8^{\circ}$ piso de Pueyrredón 1443, Sector de Coordinación de Operaciones Telefónicas Recepción de Llamadas de Urgencias Médicas, entre las 24 y 8 hs., y expresa que en dichos videos se observa a tres personas que aquel identifica, entre ellos al actor, «...que se encuentran fuera de sus puestos de trabajo en horario laboral y dirigiéndose a un lugar de descanso para pernoctar». En mi criterio, para reconocer eficacia convictiva a dichas grabaciones hubiera sido necesario que las mismas hubieran sido reconocidas por la parte contraria o por testigos o debidamente autenticada (en sentido análogo, sentencia n 9.732 del 17/7/2001, en autos «Liewiski, Laura Silvina c/ Juncadella S.A. s/ despido», del registro de la sala $10^{\text {a }}$ de esta Cámara). [...] La aludida certificación notarial no resulta eficaz para tener por auténticos tales videos pues el escribano no estuvo presente en el lugar y en el momento en que se realizaron las supuestas filmaciones, no verificó que la grabación efectivamente se realizara 
El derogado Código Civil argentino, en sus artículos 979 a 1036, se refería a la forma, recaudos y efectos de los documentos en que se plasmaran los actos jurídicos, con la denominación de instrumentos, los cuales, según emanaran o no de sujetos investidos de autoridad para hacerlo (como ser escribanos públicos, funcionarios gubernamentales, secretarios de juzgado), se podían clasificar respectivamente en públicos (arts. 979 a 1011) o privados (arts. 1012 a 1036).

El nuevo Código Civil y Comercial argentino, en sus artículos 284 a 288, se dedica a la forma y firma de los documentos en que se plasmen los actos jurídicos con la denominación genérica de instrumentos particulares, aclara en el artículo 287 que pueden estar firmados o no, en caso de que si lo estén, se denominan instrumentos privados, y, en caso contrario, instrumentos particulares no firmados, categoría que comprende todo escrito no firmado, entre otros, los impresos, los registros visuales o auditivos de cosas o hechos y, cualquiera que sea el medio empleado, los registros de la palabra y de información. En los artículos 289 a 312 contempla los instrumentos públicos, es

en su presencia, ni tampoco procedió a sellar las cintas utilizadas para evitar una previa o ulterior adulteración; como se advierte solo se limitó a transcribir las manifestaciones del representante del demandado".

Cám. Nac. Trab., sala III, 27/11/2013, "Ledesma, Walter Javier c/ Interjuegos S.A. s/ despido", elDial AA845E: "Por último, en cuanto al contenido del CD, el sentenciante concluyó, que no resulta eficaz para tener por auténtico el procedimiento utilizado para reconocer eficacia convictiva al material audiovisual acompañado como prueba. Ello, toda vez que aun mediando certificación notarial, el escribano no estuvo presente en el lugar y en el momento en que se realizaron las supuestas filmaciones, ya que el notario no verificó que la grabación fuera realizada efectivamente en su presencia, ni tampoco procedió a sellar las cintas utilizada, para evitar una previa o ulterior adulteración. Resalto que el valor probatorio por medios informáticos, grabaciones y audiovisuales en general, no se ha asentado lo bastante como para contar con pautas claras. De todos modos, en hipótesis como las de autos, en donde no contamos con ningún factor externo a la empleadora, que permita tener por seguro que no pudo mediar una adulteración, el CD tiene valor indiciario exclusivamente. Mas como no fue acompañado por ninguna otra prueba, no es suficiente para formar convicción".

Cám. Nac. Trab., sala VII, 29/12/2013, "Pager, Nicolás Esteban c/ Estancia El Solitario S.A. s/ despido", elDial AA8466: "La demandada se agravia porque la jueza de primera instancia, consideró que el medio probatorio de filmación-DVD- no resulta procedente por no encontrarse acompañado de una certificación por escribano. Al respecto, coincido con lo manifestado por la sentenciante en cuanto expresa que, para que los DVD sirvan como prueba, deben cumplir determinadas pautas, tales como estar certificada por escribano y debe ser corroborada por otras pruebas -como la testimonial-, que la avalen, lo que no se da en el presente caso". 
decir, los que emanan de sujetos investidos de autoridad para hacerlo, y a los instrumentos privados y los particulares, en los artículos 313 a 318, sobre los cuales especifica el valor probatorio en el artículo 319.

Los adelantos tecnológicos en los medios de comunicación han dado lugar al envío de mensajes de manera electrónica, como el fax -aunque podemos decir que ya es antiguo- y el correo electrónico vía Internet -e-mail-, que generan una problemática de difícil solución para los operadores jurídicos en lo que respecta al valor probatorio de tales medios.

Así, en reemplazo de la antigua correspondencia escrita en papel, salvo que la situación amerite el empleo de un medio fehaciente, aunque no es aconsejable, era moneda corriente que se usara el $f a x$, sin embargo, en la actualidad el medio más usado indudablemente es el e-mail, para enviar proyectos de contratos para su corrección, condiciones de venta con relación a operaciones determinadas, etc., los cuales muchas veces implican prueba preconstituida porque contienen información jurídicamente relevante, la cual, en muchas ocasiones no representa el objetivo principal de su envío o intercambio.

Lo que se envía y recepciona no es un objeto material como un papel escrito, es la comunicación que se realiza por interfases que traducen el lenguaje común y legible, luego de una conversión de pulsos analógicos a digitales, encriptaciones en soportes magnéticos o electrónicos, desencriptaciones a voz o papel, sea a través de un fax o de un módem, por la línea telefónica o un cable coaxil o cable módem ${ }^{21}$.

En el caso del fax, en definitiva, lo que se puede presentar en un proceso judicial es el papel escrito que fue enviado o el que fue recibido; en este último caso, a menos que se trate de un aparato de fax que funcione con papel común, será un papel especial que se irá tornando ilegible con el transcurso del tiempo, lo cual genera un inconveniente adicional, dado que la permanencia en el tiempo es una condición esencial de todo documento.

Por tanto, este es una prueba documental; la problemática radica en probar el envío, la recepción y la autenticidad del contenido del fax, pues aunque este se halle firmado, no es posible determinar la autenticidad de la firma mediante una prueba pericial caligráfica, de la misma manera que tampoco es posible hacerlo de la fotocopia de un documento firmado.

Sucede que es fácil programar en el aparato de fax el número telefónico desde el cual se envía, los datos del emisor, fecha, hora, etc. Desde esta perspectiva, si el

21 COLERIO, Juan P. "Fax, e-mail e internet. Valor como documento y como prueba". Revista de Doctrina 2 del Colegio Público de Abogados de la Capital Federal, año 1, $\mathrm{n}^{\circ} 2$. Argentina, mayo de 2000. p. 6. 
fax presentado como prueba documental es reconocido por la contraparte como enviado o recibido, y tampoco se cuestiona su contenido, entonces tendrá pleno valor probatorio, de la misma manera que lo tiene un documento privado. De lo contrario, será prácticamente imposible acreditar su autenticidad, pues, aunque mediante informes de las compañías telefónicas se confirmara el llamado desde una línea de teléfono a la otra, quedará sin acreditación el texto, el contenido del fax, ya que no queda almacenado dentro del aparato ${ }^{22}$. Esto hace aconsejable no utilizar el fax para comunicaciones importantes.

En lo que respecta a los correos electrónicos-e-mails-, es importante aclarar que se puede considerar red de Internet al sistema de interconexión de una infinidad de computadoras sin importar dónde se encuentren, por medios y servicios de comunicaciones. La comunicación que llegue a cada una de esas computadoras podrá ser común a todas o solo a alguna. La información puede provenir de archivos o de un emisor, ser generalizada o estar dirigida a un

22 Cám. Nac. Com. (Cámara Nacional de Apelaciones en lo Comercial), sala E, 17/4/2006, "Barbalia, Daniel Cristian c/ La Economía Comercial Argentina S.A. de Seguros Generales s/ ordinario", elDial.com AA3526: "De la copia de fs. 22 surge que el aviso de remisión del fax da cuenta de haber sido enviado al $n^{\circ} 4394-3168$, y ese número coincide con el de la aseguradora que se indica en la carpeta que contiene la póliza. No obstante ese señalamiento, no surge cuál es el contenido de la hoja que se transmitió, pero si hubiera sido la «denuncia policial» observo que no menciona la existencia del seguro, ni el número de póliza como en cambio surge de la denuncia copiada en fs. 182. [...] Si bien la exigencia de formalidades en las denuncias de siniestros es cuestión opinable (ver MEILIJ, Gustavo R. y BARBATO, Nicolás. Tratado de derecho de seguros. Zeus, 1975. p. 140, ap. 222) lo que es a mi juicio claro, es que esa comunicación debe ser suficiente para que el asegurador tenga conocimiento de tratarse de un siniestro que está comprendido en la cobertura que dio, requisito que no cumple la mera trascripción de la denuncia policial con los datos del automotor sustraído sin dar mayores datos sobre la existencia de seguro, lo que significa que el asegurado no cumplió con el art. 1198, Cód. Civil. [...] Si bien el fax puede considerarse un instrumento válido para probar en juicio (conf. GOZAÍNI, Osvaldo A. La teoría de la prueba y el fenómeno de la informática. en J.A. 1999-11, p. 912 y ss.) de todos modos, no basta con la simple invocación de haberlo enviado y de sostener que tenía determinado contenido, es necesario demostrar su texto y recepción sobre todo cuando como en el caso, medió negativa en ambos aspectos de la contraparte. [...] El actor que tuvo a su carga demostrar haber cursado comunicación del siniestro a su aseguradora en el plazo de ley, no logra probarlo; mientras que la demandada obtiene pruebas que revelan que tal denuncia fue cumplida tardíamente; así, es la aseguradora la que logra cumplir la carga de la prueba de los hechos que hacen a su defensa (C.P.C.C.N., art. 377). Por todo ello, concluyo que no se demostró que el actor hubiera cumplido con denunciar el siniestro en el plazo de tres días de ocurrido, y al resultar incumplida la carga del art. 46 de la ley 17.418, se produce la caducidad del seguro (L. 17.418, art. 47 ), razón por la cual corresponde rechazar la demanda". 
destinatario o grupo determinado; así, el e-mail es un subsistema de esta red mundial que consiste en un servicio que permite enviar y recibir mensajes de una computadora a otra cualquiera que se conecte a la red $^{23}$. Se asemeja al tradicional correo postal de mensajes escritos en papel; no obstante, debido a la red, será necesario un servidor que reciba el mensaje enviado y lo transmita a su o sus destinatarios, todos los cuales deberán tener una "casilla de mensajes" equivalente a la dirección postal ${ }^{24}$.

En la opinión de Bernardo Carlino, se denomina documento electrónico a toda representación digital de actos, hechos o datos jurídicamente relevantes. Este se puede encontrar firmado digitalmente, cuando se le ha aplicado una firma digital resultante de la transformación del documento digital, al emplear técnicas de criptografía asimétrica y un digesto seguro. Dicho documento resultará apto para activar un derecho, expresión que comprende tanto adquirir derechos como contraer obligaciones, y abarca todo tipo de procesamiento electrónico de datos. Asimismo, existe consenso en determinar conceptualmente las partes en que se compone el documento electrónico: el soporte (elemento material que contiene la declaración, de naturaleza electrónica), la grafía (representación externa, para lo que se vale de un medio y de un lenguaje) y la declaración contenida (contenido del documento). Dentro del género del documento electrónico, se distingue una de sus especies: el instrumento informático, que se define como aquel documento que se instrumenta y se manifiesta en grafía legible y en soporte papel ${ }^{25}$.

Según el artículo $6^{\circ}$ de la Ley 25.506 -de firma digital-, el documento digital es la representación digital de actos o hechos, con independencia del soporte utilizado para su fijación, almacenamiento o archivo, y se aclara que un documento digital también satisface el requerimiento de escritura.

La Ley Modelo de la CNUDMI (UNCITRAL) sobre las firmas electrónicas (2001) -art. 2, inc. $c_{-}$, al igual que la Ley Modelo de la CNUDMI sobre comercio electrónico (1996) -art. 2, inc. a-, define al mensaje electrónico de datos como la "información generada, enviada, recibida o archivada o comunicada por medios electrónicos, ópticos o similares, como pudieran ser, entre otros, el

23 FALCÓN, Enrique M. Derecho procesal civil, comercial, concursal, laboral y administrativo. t. I, Santa Fe, Argentina: Rubinzal-Culzoni, 2003. p. 631.

24 Instituto de Derecho Procesal Civil y Comercial del Colegio de Abogados del Departamento Judicial de San Martín, Argentina -director Héctor Eduardo Leguisamón-, El e-mail y sus dificultades probatorias, ponencia presentada al XXII Congreso Nacional de Derecho Procesal (Paraná, Entre Ríos, Argentina, 2003), elDial.com DC2A4.

25 CARLINO, Bernardo P. Firma digital y derecho societario electrónico. Santa Fe, Argentina: Rubinzal-Culzoni, 1998. pp. 35/36. 
intercambio electrónico de datos (EDI), el correo electrónico, el telegrama, el télex o el telefax" ${ }^{26}$.

En consecuencia, se puede decir que los mensajes electrónicos de datos deben ser considerados documentos. Sin embargo, la problemática radica en determinar si esos mensajes de datos producidos en soportes electrónicos, magnéticos, o a través de fibra óptica, toleran los requerimientos básicos de confiabilidad de todo documento: inalterabilidad, autoría y durabilidad.

Sin embargo, en Argentina la institucionalización de la firma digital por medio de la Ley 25.506 no tuvo la repercusión esperada, pues a más de catorce años de su sanción y entrada en vigencia ${ }^{27}$, todavía es difícil encontrar a una persona que tenga habilitado el sistema para firmar documentos digitalmente. Así, se encuentra generalizado el uso de mensajes de datos que no tienen firma digital -comúnmente denominados e-mails-, lo cual provoca el problema de determinar su eficacia probatoria, caso que también se da cuando la firma digital no cumple con los parámetros de validez dispuestos por la Ley 25.506 y su Decreto reglamentario 2.628/2002.

$\mathrm{Al}$ igual que con el fax, lo que materialmente se puede presentar es una impresión en papel del $e$-mail, si al contestar el traslado, el envío o la recepción de aquel, fuera reconocido o no fuera desconocido expresamente por la parte contraria, tiene absoluto valor probatorio. El problema se presenta cuando la recepción o el envío del e-mail son negados. Su valor probatorio dependerá de la acreditación del envío y la recepción de él ${ }^{28}$.

26 http:www.uncitral.org/sp-index.htm.

27 Sancionada el 14/11/2001, promulgada de hecho el 11/12/2001, y publicada en el B.O. el $14 / 12 / 2001$.

28 Cám. Nac. Com., sala D, 4/10/2007, "Baires Inter Trade S.A. c/ Otro Mundo Brewing Company S.A. s/ medida precautoria”, elDial AA499B: "No cabe, como regla, asignar valor probatorio a un correo electrónico que no cumple con los requisitos de los arts. $2^{\circ}$ y $5^{\circ}$ de la Ley 25.506 sobre «firma digital» (conf. Cám. Nac. Com., sala A, 27/6/2006, «Coop. de Viv. Créd. y Cons. Fiduciaria Ltda. c/ Becerra Leguizamón, H.», L.L. del $24 / 10 / 2006$, fallo $n^{\circ} 110.898$ ) ya que el elemento de autenticación o certificación es un requisito esencial en la formación del denominado documento electrónico (conf. esta sala D, causa 7611/03 «Henry Hirschen y Cía. S.A. c/ Easy Argentina S.R.L. s/ ordinario», sentencia del 16-2-2007; NIETO MELGAREJO, P. Derecho del comercio electrónico. Lima, 2005. pp. 126/127)".

Cám. Nac. Com., sala D, 2-3-2010, “Bunker Diseños S.A. c/IBM Argentina S.A.”, L.L. del 3/6/2010, p. 7: "I) En el valor probatorio del correo electrónico ocupan un lugar preeminente a partir de la vigencia de la Ley 25.506 los documentos con la firma digital, en tanto su valor probatorio es equiparable al de los instrumentos privados y se presume la autoría e integridad del mensaje, correspondiendo a la otra parte destruir tales pre- 
Si bien no es sencillo, es factible acreditar estas circunstancias mediante un pedido de informe a la empresa en la cual se encuentra la cuenta de correo electrónico -la dirección de e-mail- (v.gr., una cuenta hotmail.com, a la empresa Microsoft) sobre todos los datos que registre de su titular (nombre y apellido, número de documento, domicilio, etc.) y las direcciones IP que se hallen en el

sunciones (v. HOCSMAN, H. Negocios en Internet. cap. II, n 63.b, 2005. ps. 162/164). II) Pero aun cuando en este caso se trata de documentos que carecen de firma digital a los que no puede otorgarse un valor de convicción preeminente por no cumplir con los requisitos de los arts. $2^{\circ}$ y $5^{\circ}$ de la Ley 25.506 sobre «firma digital» puesto que el elemento de autenticación o certificación es un requisitos esencial de autenticidad (conf. esta sala, 16/2/2007, «Henry Hirschen y Cía. S.A. c/ Easy Argentina S.R.L.»), no existe impedimento a mi juicio para que se los ofrezca como medio de prueba (C.P.C. 378:2), considerándoselos principio de prueba por escrito como había aceptado la doctrina de los autores antes de la sanción de la citada Ley 25.506. Tal valor probatorio se sustenta en las normas del Cód. Civil 1190, 1191, 1192, pues aunque por no estar firmados no alcancen a la categoría de documento privado, es admisible su presentación en juicio para probar un contrato siempre que emanen del adversario, hagan verosímil el hecho litigioso y que las restantes pruebas examinadas a la luz de la sana crítica corroboren su autenticidad. Por lo tanto, es decisiva la prueba complementaria que se produzca merituada conforme con los criterios de la sana crítica y conjuntamente con las restantes pruebas del proceso (vid. esta sala, 26/9/2006, «Gómez, Fabián c/Banco de la Ciudad de Buenos Aires»; KIELMANOVICH, J. Teoría de la prueba y medios probatorios. cap. XI, n 2, c y 3, 2004. pp. 393/398; SOMER, M. Documento electrónico. J.A. 2004-I, pp. 1034/1035; GAIBROIS, L. Un aporte para el estudio del valor probatorio del documento electrónico. J.A. 1993-II, ap. IX, p. 963). III) Con base en esos parámetros y tas un nuevo examen de los elementos de convicción agregados a la causa debe coincidirse con la apreciación de la señora juez de la primera instancia en cuanto a que existía entre las partes la costumbre de formular los pedidos de trabajo en forma verbal antes de la remisión de las notas de pedido. Tal conclusión se sustenta en que: A) La demandada nunca negó el carácter de empleado de IBM del mencionado Galache, quien además envió los e-mails desde una casilla institucional: galache@ar.ibm.com. Considero como un hecho público y notorio (v. COUTURE, E. Fundamentos del derecho procesal civil. $\mathrm{n}^{\circ} 150,1993$. p. 233) en este sentido que una dirección de correo electrónico es individual y que no pueden registrarse dos iguales, por lo que no puede presumirse sin ninguna duda razonable que la sigla IBM pertenece a la demandada (v. LEGUISAMÓN, H. Las presunciones judiciales y los indicios. cap. IX, $\mathrm{n}^{\circ}$ A.2, 1991. p. 92). B) Tampoco desconoció la demandada en fs. 84 los mensajes de correo electrónico agregados por la actora de fechas 11/7/2003, 23/4/2003; 22/4/2003 y 25/3/2003 (fs. 31/34) cursados a la dirección pulice@ar.ibm.com malito:pulice@ar.ibm.com y en algunos casos respondidos, así como el de fs. 43 dirigido a cabrera@ar.ibm.com del 27/1/2003 ante un pedido de cotización, los cuales revelan que eran usuales las tratativas precontractuales y poscontractuales entre las partes por ese medio. C) En el informe pericial de fs. 191/198 se informó la efectiva constatación de la existencia de veinticinco gabinetes metálicos en la planta de aquella, y si bien este informe fue impugnado por la demandada la crítica se circunscribió a la determinación del valor de venta de cada unidad (v. fs. 201/203)". 
historial de los log's de las conexiones realizadas en un lapso determinado. Con las direcciones de IP informadas, se puede establecer el proveedor del servicio de Internet con el cual se realizaron las conexiones y, con un informe requerido a este, los datos del usuario de las direcciones $\mathrm{IP}^{29}$.

Pero aunque esas circunstancias estén acreditadas, el problema persiste si el contenido del e-mail es negado. Una posibilidad para probarlo sería la de requerir informe al servidor de Internet por el cual fue enviado el $e$-mail. Pero resulta ser que no hay una normativa que establezca que los servidores deban mantener los mensajes por un tiempo determinado, con lo cual no podrían informar si el mensaje fue efectivamente recibido o enviado, ni tampoco su contenido. Hay servidores que los almacenan durante cierto tiempo, de acuerdo a las condiciones de contratación con los usuarios, pero esta posibilidad, obviamente, no es confiable, menos aún si se trata de un servidor extranjero. Pero, aunque pudieran informar sobre el envío y/o recepción de un e-mail, no podrían hacerlo sobre su contenido en lo que hace a su autoría e inalterabilidad. De aquí, que este no resulte una prueba de extrema seguridad ${ }^{30}$.

29 Cám. Nac. Civ., sala A, 5/2008, L. 494.472, "Biggest Bank S.A. c/ Corporate Business Solutions S.R.L. s/ daños y perjuicios", inédito: "El acto que aquí se califica como un "proceso técnico complejo» que resultaría uno de los hechos inidóneos como objeto de dación de fs. (v. fs. 233 vta.) es la conexión a Internet. Pero basta con advertir que ese acto lo realiza a diario hasta un niño de 4 años para concluir en la inexactitud de esa afirmación. No veo qué puede tener de completo conectarse a Internet a estas alturas, cuando basta con hacer un «click» en la computadora (ahora hasta puede hacérselo de un teléfono celular u otros aparatos electrónicos) para acceder a la red. De allí que sea francamente inadmisible sostener que un escribano carece de idoneidad para conectarse a Internet, siendo irrelevante que en el acto no se hubiera indicado en qué lugar se hizo la conexión, sobre qué aparato electrónico, en qué máquina se imprimieron las hojas que dieron cuenta del uso de las imágenes ni quién usó la computadora u otro elemento, porque lo cierto es que la escribana estaba presente cuando se accedió a la red y las imágenes pasaron ante su vista. Es cierto que de acuerdo al informe elaborado por el Instituto Nacional de Tecnología Industrial (v. fs. 164) es técnicamente posible redireccionar un nombre de dominio hacia otra dirección IP, pero en todo caso, tal contingencia debió ser demostrada por el recurrente, porque no es razonable hacer pesar sobre el demandante una exhaustiva investigación para corroborar que nadie hubiere cambiado la dirección IP. Si en la página cuyo dominio pertenece a la empresa demandada había imágenes cuyos derechos patrimoniales correspondían a la actora, debe presumirse que la emplazada explotaba su uso y corría por su cuenta demostrar que un tercero adulteró el sistema, sea ingresando esas imágenes en la página, redireccionando el nombre de dominio a otra dirección IP o utilizando otro mecanismo técnico que no le sea imputable a la empresa accionada".

30 Cám. Civ. Com. Pergamino, Argentina, 8/4/2014, “G., M. L. c/ G., M. A. s/ división de condominio", elDial AA87DA: "Con respecto a la validez de los «correos electrónicos», independientemente de tal circunstancia, debo adelantar que pese a su intento recursivo, 
Más idónea aparece la prueba pericial a realizar sobre el ordenador (la PC) desde el cual fue supuestamente enviado o recibido el e-mail, a cargo de un ingeniero en sistemas o experto en criptología, o la especialidad que en el futuro la técnica indique como adecuada. El mensaje de datos objeto de la pericia tiene el inconveniente de que puede ser fácilmente eliminado o alterado del equipo de la PC; esto nos lleva a que la producción de la peritación se debería realizar de manera anticipada ${ }^{31}$, complementada con el secuestro del equipo

no se logra conmover lo decidido por el a quo. Es que, lo primordial es señalar que a la parte interesada en la acreditación de un hecho o circunstancia, tiene la carga probatoria sobre la misma, y en nuestro caso ante el desconocimiento categórico efectuado por la parte actora respecto los «correos electrónicos» alegados por la apelante, tocábale a su parte la carga de la prueba al respecto (C.P.C.C., art. 375, Buenos Aires). Y, en tal tarea entiendo que no ha tenido el éxito de esperar, en tanto que los oficios librados a las empresas que ella solicitara información al respecto (Yahoo Argentina, Hotmail y Blackberry), resultaron negativos, es más, a las dos últimas entidades no fueron diligenciados, hecho reconocido expresamente por la recurrente a fs. 127, punto I. Precisamente, la empresa «Yahoo Argentina» contestó sobre el particular, que: «... si bien quisiéramos cooperar con vuestra causa, nos vemos imposibilitados de confirmar si el correo electrónico adjunto al oficio en responde, en realidad fue intercambiado por los usuarios mencionados o si el contenido del mismo es igual al que surge en la documentación adjunta al oficio en responde. Esto, por cuanto que los correos electrónicos pueden ser alterados, vulnerados y modificados por terceros ajenos a los usuarios de dichas cuentas, por limitaciones técnicas y cuestiones de privacidad de nuestros usuarios, no podemos ingresar a las cuentas de los mismos y acceder específicamente a los correos intercambiados por los usuarios con determinadas cuentas y/o personas» (fs. 111). Posteriormente y ante una nueva requisitoria, la misma empresa contestó, adjuntando un $\mathrm{CD}$ «con el contenido completo de la cuenta de correo electrónico de dicho usuario en el período solicitado. Sin embargo, hago de su conocimiento que YAHOO no realiza respaldos o almacenamiento de la información contenida en una determinada cuenta de correo electrónico. Dicha información depende de lo que el titular de la cuenta desee o no almacenar o conservar en la misma» (fs. 143). Y, ante tal contestación la parte demandada nada hizo para en definitiva lograr acreditar la autenticidad de la prueba que su parte intentaba hacer valer para sostener su posición".

31 Cám. Nac. Trab, sala III, 29/10/2010, "Palavecino, Favio Néstor c/ Carl Zeiss Argentina S.A. s/ diligencia preliminar", elDial AA65D8: "Que lo expresado pone de relieve que, el adelanto probatorio peticionado, está destinado a resguardar la integridad de la prueba contenida en los archivos que obrarían en la computadora y el teléfono celular y que consistirían, en lo esencial, en los e-mails que tuvieron lugar entre las partes. El objeto de la medida se circunscribe a que tales instrumentos queden depositados en la sede del juzgado hasta tanto se lleve a cabo la prueba pericial (fs. 17 vta.). Que, reseñado lo acontecido, vale resaltar que en el caso nos encontramos frente a un despido directo con invocación de causa y que, en lo esencial, los incumplimientos contractuales que se imputaron al trabajador se sustentaron en el contenido de ciertos e-mails, presumiblemente remitidos desde la laptop consignada, y por el indebido uso del teléfono celular 
de computación de que se trate, sin que su propietario tenga conocimiento con anterioridad -para evitar el riesgo de que los archivos sean eliminados o alterados-, bajo la intervención del defensor oficial para que se encuentre garantizado su derecho de defensa en juicio (C.P.C.C.N., art. 327) ${ }^{32}$. Se debe tener en cuenta, especialmente en este sentido, la modificación introducida por la Ley 25.488 mediante la incorporación del inciso 4 al artículo 326 del C.P.C.C.N., que permite proceder al secuestro del equipo de computación ${ }^{33}$.

No obstante, aunque se pudiera determinar mediante la prueba pericial la existencia del $e$-mail en el equipo receptor o emisor, de todas maneras quedaría sin determinar la autoría del documento, pero es innegable que se trata de un indicio grave de su existencia como para presumirla ${ }^{34}$.

BlackBerry. Por otra parte, la pretensión del actor está dirigida a impugnar no solo el motivo invocado por la empleadora para rescindir el vínculo laboral sino, además, el acoso laboral del que, según sus dichos, habría sido víctima, que también se fundan en las comunicaciones que habrían tenido lugar a través de los instrumentos de marras. Que, desde esta perspectiva, cabría concluir que, en verdad, ambas partes estarían interesadas en preservar la integridad de los archivos que obran en las herramientas de trabajo aquí depositadas y, lo decisivo es que admitir la medida no conlleva una intromisión «sorpresiva» y general en el sistema informático de la accionada ni, por ende, una injerencia en la órbita de instrumentos privados, ya que solo se limita al análisis de aquellos que fueron de uso personal del dependiente durante el curso de la relación laboral. Que en estas condiciones, corresponde revocar lo decidido en grado y acoger la pretensión del actor. Que, sin embargo, vale hacer una aclaración. Toda vez que la computadora y el celular Black Berry son bienes muebles de propiedad de la demandada, que esta utilizaría para el ejercicio de su actividad económica y que se encuentran amparados por el derecho constitucional de propiedad (Const. Nac., arts. 14 y 17), corresponde que, previa citación de la contraria (C.P.C.C.N., art. 327) y de acuerdo con lo previsto por el art. 326 del mismo cuerpo legal, se produzca en forma inmediata la prueba pericial a cuyo fin las partes deberán ofrecer los respectivos puntos de pericia. De lo contrario, podría correrse el riesgo que la eventual dilación del proceso conlleve a privar a la accionada no solo del uso y goce de bienes de su propiedad sino que, incluso, podría afectarse su valor e importancia por el mero transcurso del tiempo".

LEGUISAMÓN, Héctor Eduardo. El secuestro de la historia clínica como prueba anticipada. L.L. 1993-E-221.

33 LEGUISAMÓN, Héctor Eduardo. Los adelantos tecnológicos y sus dificultades probatorias, en E-mails, chats, mensajes de texto, facebook y dvd. Validez probatoria en el proceso civil, comercial, penal y laboral. Estudio doctrinal y jurisprudencial. Horacio R. Granero (dir.). elDial.com, Buenos Aires, 2014. pp. 83-85

34 Instituto de Derecho Procesal Civil y Comercial del Colegio de Abogados del Departamento Judicial de San Martín, Argentina. El e-mail y sus dificultades probatorias. Ob. cit. 
La situación es más complicada cuando se trata de mensajes de texto de teléfonos celulares ${ }^{35}$.

El artículo 319 del nuevo Código Civil y Comercial establece que el valor probatorio de los instrumentos particulares debe ser apreciado por el juez ponderando, entre otras pautas, la congruencia entre lo sucedido y narrado, la precisión y claridad técnica del texto, los usos y prácticas del tráfico, las relaciones precedentes y la confiabilidad de los soportes utilizados y de los procedimientos técnicos que se apliquen, como también las videocintas que ahora están contempladas en el artículo 287 del mismo cuerpo legal como instrumentos particulares no firmados.

Por su lado, el artículo 318 del mismo nuevo Código Civil y Comercial establece que "la correspondencia, cualquiera sea el medio empleado para crearla o transmitirla puede presentarse como prueba por el destinatario", frase que obviamente comprende a los correos electrónicos -e-mails-. También su artículo 286 se refiere a la utilización de cualquier soporte con texto inteligible, aunque su lectura exija medios técnicos para los instrumentos públicos, privados o particulares no firmados. Asimismo, su artículo 288, relativo a los instrumentos generados por medios electrónicos, prescribe que el requisito de la firma de una persona queda satisfecho si se utiliza una firma digital -que en mi opinión no es estrictamente la que instauró la Ley 25.506, sino una simplemente electrónicaque asegure indubitablemente la autoría e integridad del instrumento.

Sea que se utilicen los e-mails sin firma digital o el documento digital firmado digitalmente, por ahora no resolveremos el problema de la seguridad jurídica, dado que el manejo de la carga de la información es humana, así como aquellos que exprimen su ingenio en la búsqueda de burlar y traspasar las barreras de los códigos de seguridad de los sistemas informáticos ("hackers"), y otros que denodadamente, sin escatimar esfuerzos -y hasta por diversión-, tratan de elaborar los tan temidos virus que los contaminan y hacen que se tornen inoperables. Recordemos que nadie puede alegar su propia torpeza, y a esta altura de la informática y su suerte jurisprudencial ${ }^{36}$, es aconsejable utilizar los e-mails

35 Cám. Nac. Com., sala A, 5/6/2012, "Barcos, Juan Carlos c/ Urcelay, Gustavo s/ ejecutivo", elDial AA796C: "En autos se ejecuta un contrato de mutuo, por lo que la discusión que se propone, relativa a atribuir eficacia probatoria a mensajes de texto, vía celular (que el ejecutante niega haber enviado), excede el campo acotado del proceso ejecutivo, dadas la abstracción, literalidad y autonomía propias del título en ejecución, lo que conlleva, también, la improponibilidad de la audiencia requerida por el ejecutado en esta Alzada".

36 Cám. Nac. Trab., sala VIII, 31/10/2005, Exp. n 18.885/2004, "Mullins, Maria E. c/ Stratford Book Services S.A. s/ despido", elDial.com AA2FA3: "La actora cuestiona la fecha de ingreso. Dice que la prueba informativa da cuenta de que los mensajes de correo 
sin firma digital como mero medio de comunicación, mas no para cuestiones de trascendencia jurídica ${ }^{37}$.

\section{DISTINTOS “DOCUMENTOS” Y LA PRESENTACIÓN DE COPIAS.}

El problema se presenta cuando hay que dar cumplimiento con la carga de acompañar copia de determinados "documentos" - muchas veces logrados como prueba preconstituida-, agregados generalmente con la demanda y con la contestación de demanda, para que se corra traslado de ellos.

Según el artículo 121 del C.P.C.C.N. -como en la mayoría de los códigos procesales provinciales-, se puede eximir al litigante de esa carga cuando la reproducción fuese dificultosa por su número, extensión, o cualquier otra razón atendible, en cuyo caso el juez debe arbitrar las medidas necesarias para obviar los inconvenientes derivados de la falta de copias.

electrónico enviados por ella a un número determinado de hoteles desde el domicilio electrónico de la demandada son de fecha anterior a su registración, elemento probatorio, insiste, de entidad suficiente para acreditar la falsedad de los datos registrados. El recurso es improcedente. La copia de los mails acompañados por la quejosa no son hábiles para arribar a una razonable conclusión sobre los hechos expuestos. Si bien los informes de los hoteles confirman que aquellos fueron enviados por la empresa S.B.S., ellos no son eficaces para identificar la persona que los remitió, máxime cuando la dirección de la casilla estaba bajo el nombre «Parque Chacabuco». Si bien en el contenido de los mails figura al final del texto el nombre «Maureen», apodo de la actora, el mismo no se asimila a la firma digital, por lo que no tiene más valor que el de un indicio -tal como sostiene la a quo- dado que no fue corroborado por ningún otro elemento probatorio, deficiencia que deberá asumir en los términos del art. 377 del C.P.C.C.N..

Cám. Nac. Com., sala D, 4/10/2007, causa n 41664/2007, "Baires Inter Trade S.A. c/ Otro Mundo Brewing Company S.A. s/ medida precautoria", elDial.com AA449B: "La provisión de un e-mail que habría sido remitido por un tercero ajeno a las partes, amén de la ausencia de signos o elementos que demuestren su autenticidad, constituye una pieza inconsistente a los fines probatorios pretendidos. [...] No cabe, como regla, asignar valor probatorio a un correo electrónico que no cumple con los requisitos de los arts. $2^{\circ}$ y $5^{\circ}$ de la Ley 25.506 sobre «firma digital» (conf. Cám. Nac. Com., sala A, 27/6/2006, «Coop. de Viv. Cred. y Cons. Fiduciaria Ltda. c/ Becerra Leguizamón, H.», L.L. 24/10/2006, fallo ${ }^{\circ} 110.898$ ) ya que el elemento de autenticación o certificación es un requisito esencial en la formación del denominado documento electrónico (conf. esta sala D, causa 7.611/03 «Henry Hirschen y Cía. S.A. c/ Easy Argentina S.R.L. s/ ordinario», sentencia del 16/2/2007; Nieto Melgarejo, P., Derecho del comercio electrónico, Lima, 2005, pp. 126/7)". 
Cuando se trata de grabaciones en casetes, videograbaciones, $\mathrm{CD}$-compact discs-, disquetes, DVD, y otros medios informáticos o de grabación modernos, como ocurre cada vez con mayor frecuencia, si bien se pueden copiar, es imposible firmarlos por la parte o su letrado a modo de autenticación o garantía de que son copia fiel de los originales como lo prescribe el artículo 120 del C.P.C.C.N., así, la dificultad radica en constatar a simple vista que su copia se corresponde con el original presentado.

En estos casos, dependerá de los medios técnicos con los que cuente el juzgado para que el litigante contrario pueda examinarlos; si no los posee, entonces, se podría designar una audiencia para que en ella, y con el elemento técnico que deberá proporcionar quien lo presentó, la otra parte pueda examinarlo ${ }^{38}$.

En un caso en el cual me toca intervenir, la parte contraria agregó con su contestación de demanda un $\mathrm{CD}$, diciendo que contenía la representación dinámica de la secuencia de la mecánica de un accidente de tránsito que había sido elaborada por un ingeniero mecánico mediante el empleo de un software especial.

Al contestar el traslado que se me corrió, expuse que me veía imposibilitado de contestar categóricamente hasta tanto no tuviera la posibilidad de examinar el CD, para cuyo efecto pedí que se designara una audiencia. Después de varios años y hasta el momento, no tuve la posibilidad de responder porque solo se tuvo presente mi pedido. Y aunque la parte contraria hubiese acompañado copia del CD, la situación no habría variado, porque hubiera sido necesario cotejar si esa copia se correspondía con el original.

En otro caso, era necesario preconstituir prueba que constatara por un escribano público el contenido de la página web de la futura parte demandada que favorecía la posición de la actora, pues sería muy fácil para el demandado alterar el contenido o directamente suprimir la página web una vez que tomara conocimiento de la demanda. Sin embargo, no era posible imprimir las distintas pantallas de la página web para que las certificara el notario, como había hecho en otra oportunidad, puesto que la página web era dinámica, las imágenes tenían movimiento, no solo por algunas videograbaciones, sino porque el texto iba corriendo a medida que se lo leía.

Opté entonces por realizar una copia de la página web en un CD y que el notario la certificara. Lo que en teoría no tenía inconvenientes, en la práctica,

38 LEGUISAMÓN, Héctor Eduardo. Los adelantos tecnológicos y los problemas en la preconstitución de prueba y producción de prueba anticipada. Ponencia presentada al XXV Congreso Nacional de Derecho Procesal (Buenos Aires, 2009), Libro de Ponencias. pp. 454/456; página web del Congreso http://www.procesal2007mdp.com.ar/buscador.htm, y elDial.com DCE2E; y Derecho procesal civil. Op. cit. t. I, pp. 222/223. 
parecía imposible encontrar al técnico que tuviera suficientes conocimientos como para hacerlo. Finalmente, se encontró y el notario constató el procedimiento de copiado y que el contenido del CD efectivamente era copia de la página web.

Pero como la firma sobre el CD no significa que luego no se pueda alterar lo grabado en él, el escribano labró un acta de comprobación en la cual dejó constancia del contenido de la página web y de todos los pasos efectuados, a la cual anexó copias certificadas de impresiones de distintas pantallas e introdujo el $C D$ en un sobre que cerró y firmó adecuadamente para que si fuese abierto se destruyera su firma.

En esas condiciones agregué con la demanda el acta notarial con el CD y acompañé copia también de este. En realidad, aunque la parte contraria tuvo a su disposición una copia del CD, no le era factible verificar si el contenido del $\mathrm{CD}$ agregado como copia se correspondía con el que está en el sobre cerrado sin que este fuera abierto.

Claro, se podría haber abierto el sobre en una audiencia, verificado que la copia en el CD correspondía al del sobre, para lo cual se debería contar en el tribunal con una PC que pudiera leer los CD, y luego, volver a cerrar el sobre y que este fuera firmado adecuadamente por el secretario o incluso el juez; pero nada de esto se hizo.

\section{LAS VIDEOGRABACIONES Y LA PRUEBA ANTICIPADA.}

Otro supuesto significativo de los inconvenientes que provocan al operador jurídico los avances tecnológicos con relación a la preconstitución de prueba y a las medidas conservatorias de pruebas (prueba anticipada) lo encontramos en los casos de informaciones periodísticas falsas o de injurias o calumnias proferidas a través los medios de comunicación, cuando el medio es radial o televisivo.

La prueba -podríamos decir- crucial para determinar la responsabilidad de la emisora, es la grabación del espacio radial o televisivo en el cual fue propalada la noticia falsa, la injuria, la calumnia, etc., ya se trate el mencionado espacio de un noticiero, programa, audición, sección, flash informativo, placa de noticia de último momento o de cualquier otro tipo, aparecidos en la imagen televisiva, tanda publicitaria, etc.

Para obtener esa fonograbación o videograbación es admisible proceder a su secuestro como prueba anticipada, además, sin que la emisora tenga un previo conocimiento de que se realizará, a fin de evitar que la altere o la oculte y manifieste simplemente que no realizó la grabación de la emisión, pues de 
todas maneras su derecho de defensa en juicio queda asegurado, por cuanto participará de la diligencia ${ }^{39}$.

La Ley 25.488 reformadora del C.P.C.C.N. se quedó a mitad de camino, ya que, si bien incorporó el inciso 4 al artículo 326 y permitió el secuestro de documentos como prueba anticipada, no estableció concretamente de qué manera se debe proceder.

En un caso solicité como prueba anticipada el secuestro de la grabación videográfica de la emisión de un canal de televisión, entre dos horas determinadas, en las que se había difundido una noticia falsa.

El juez hizo lugar a la prueba anticipada, pero en lugar de ordenar el secuestro de la videograbación de la emisión, dispuso que se efectuara una copia de ella por entender que debía quedar el original en la emisora, por si algún justiciable la requiriese. Con este fin, ordenó que personal idóneo de la Policía Científica de Gendarmería Nacional prestara colaboración al oficial de justicia -auxiliar del juez que realiza las diligencias delegables fuera del tribunal- a efectos de resguardar que la copia se realizara en el canal sin riesgo de adulteración o supresión. Todo lo anterior, aun cuando, ya de por sí, había sido una complicación coordinar con el oficial de justicia y con las autoridades de la Gendarmería Nacional el día y hora de la diligencia.

Se realizó la copia de la grabación de la emisión televisiva en dos videocasetes; el oficial de justicia labró el acta pertinente y los videocasetes fueron introducidos en un sobre adecuadamente cerrado y firmado, que al día siguiente fue entregado en el juzgado.

Posteriormente, para poder analizarla, peticioné que se dispusiera el medio por el cual pudiera tener acceso y ver la copia de la videograbación efectuada. La resolución fue la siguiente: "A fin de permitir a la actora examinar la documentación grabada y, al mismo tiempo resguardar su seguridad, requiérase de Policía Científica de la Gendarmería Nacional -Dirección de Pericias- la emisión de una copia de seguridad. A tal fin líbrese oficio en el que se solicitará se sirva designar personal autorizado para que se constituya en el juzgado a efectos de recibir los dos video-tapes copiados y, una vez realizada la nueva copia, proceda a su devolución ante la actuaria [secretaria del tribunal]".

El oficio se libró, personal de Gendarmería Nacional retiró los videocasetes, realizó las copias y devolvió los originales con la nueva copia. Todo ello insumió dos meses, para poder examinar la copia de la grabación de la emisión.

39 LEGUISAMÓN, Héctor Eduardo. Los adelantos tecnológicos y los problemas... Op. cit. pp. $148 / 149$. 
En otro caso en el que un programa de televisión por aire originó daños y perjuicios, acompañé la grabación videográfica en DVD de la emisión de los tres programas. El juez ordenó igualmente que se requiriera al canal de TV remitir copia videograbada de los programas. El canal de TV cumplió con la orden judicial y envió tres DVD. Entonces, solicité que se fijara una audiencia para verificar si el contenido de esos tres DVD se correspondía con las videograbaciones acompañadas con la demanda. La audiencia fue designada para más de veinte días después. Dado este tiempo excesivo, convine con el denominado "audiencista" -empleado del tribunal encargado normalmente de llevar a cabo las audiencias- en ir al juzgado un día que no tuviera audiencia, para poder efectuar la verificación sin tener que esperar tantos días. Esto se realizó con autorización del juez y dicho examen dio como resultado que las videograbaciones no se podían ver.

\section{BIBLIOGRAFÍA.}

BORDA, Guillermo A. Tratado de derecho civil-Familia-. Buenos Aires: Abeledo Perrot.

BOSSERT, Gustavo A. y ZANNONI, Eduardo A. Régimen legal de filiación y patria potestad -Ley 23.264-. Buenos Aires: Astrea, 1985.

CARLINO, Bernardo P. Firma digital y derecho societario electrónico. Santa Fe, Argentina: Rubinzal-Culzoni, 1998.

COLERIO, Juan P. "Fax, e-mail e internet. Valor como documento y como prueba". Revista de Doctrina 2 del Colegio Público de Abogados de la Capital Federal. Argentina, año $1, \mathrm{n}^{\circ} 2$, mayo de 2000 .

DÍAZ DE GUIJARRO. Valoración probatoria de la negativa a someterse a la investigación de los grupos sanguíneos. J.A. (Jurisprudencia Argentina) 1947-III-216.

DUTTO, Ricardo J. "El derecho identitario del niño. Significación y valoración de las pruebas biológicas". Revista de Derecho Procesal. vol. 2002-2, Derecho procesal de familia. Santa Fe, Argentina: Rubinzal-Culzoni, 2002.

FAIRÉN GUILLÉN, Víctor. Doctrina general del derecho procesal. Barcelona: Bosch, 1993.

FALCÓN, Enrique M. Derecho procesal civil, comercial, concursal, laboral y administrativo. t. I. Santa Fe, Argentina: Rubinzal-Culzoni, 2003.

FARINA, Marta. "El documento notarial y la prueba preconstituida”. Revista notarial, año 83, n 833. La Plata, Argentina: Colegio de Escribanos, 1977.

Instituto de Derecho Procesal Civil y Comercial del Colegio de Abogados del Departamento Judicial de San Martín, Argentina -director Héctor Eduardo Leguisamón-, El e-mail y sus dificultades probatorias, ponencia presentada al XXII Congreso Nacional de Derecho Procesal (Paraná, Entre Ríos, Argentina, 2003), elDial.com DC2A4.

JEFFREYS, Alec J., et al. Individual-specific fingerprints of human DNA, Nature. 314: 67/73, 1985. 
DIFICULTADES PROBATORIAS DE LOS ADELANTOS TECNOLÓGICOS

LEGUISAMÓN, Héctor Eduardo. Lecciones de derecho procesal civil. Buenos Aires: Depalma, 2001.

Las presunciones judiciales y los indicios. $2^{\text {a }}$ ed. actual. y ampli. Santa Fe, Argentina: Rubinzal-Culzoni, 2006.

----- Derecho procesal civil. Santa Fe, Argentina: Rubinzal-Culzoni, 2009.

-.-.-- Los adelantos tecnológicos y sus dificultades probatorias, en E-mails, chats, mensajes de texto, facebook $y d v d$. Validez probatoria en el proceso civil, comercial, penal y laboral. Estudio doctrinal y jurisprudencial. Horacio R. Granero (dir.), elDial.com, Buenos Aires, 2014.

- El hábeas data y la legislación nacional. Los daños punitivos: una herramienta necesaria. Tesis doctoral defendida y aprobada el 28/4/2011 en la Universidad del Museo Social Argentino, Argentina; a editar por editorial Rubinzal-Culzoni, Santa Fe, Argentina.

------- El secuestro de la historia clínica como prueba anticipada. La Ley 1993. E-221.

------- Prueba científica de ADN vs. cosa juzgada en procesos de filiación. Ponencia presentada al XXIV Congreso Nacional de Derecho Procesal (Mar del Plata, 2007), Libro de Ponencias; página web del Congreso http://www.procesal2007 mdp.com.ar/buscador.htm, y elDial.com DCE2E.

Los adelantos tecnológicos y los problemas en la preconstitución de prueba y producción de prueba anticipada. Ponencia presentada al XXV Congreso Nacional de Derecho Procesal (Buenos Aires, 2009), Libro de Ponencias; página web del Congreso http:// www.procesal2007mdp.com.ar/buscador.htm, y elDial.com DCE2E.

MERCADER, Amílcar. La jurisdicción y la prueba. Investigaciones en el cuerpo humano. La Ley 23-120.

MORELLO, Augusto M. La prueba científica. La Ley 1999. C-897.

PORZIO, Paula Eugenia. La actividad probatoria preliminar. ¿Sería necesaria su regulación? elDial.com DC101C.

ZANNONI, Eduardo A. Derecho de familia. Buenos Aires.

--.--- y BOSSERT, Gustavo A. Régimen legal de filiación y patria potestad -ley 23.264-. Buenos Aires: Astrea, 1985.

114 Revista del Instituto Colombiano de Derecho Procesal • No. 41 